\title{
Research on the Definition and Development Evaluation of the Connotation and Extension of Resource-Based Areas
}

\author{
Yanyan Dai*, Yang Dong, Wenxiang Zhao \\ Students Innovation and Entrepreneurship and Development Center, Shenyang Jianzhu University, \\ 100168, Liaoning Province, Shenyang City, China \\ Corresponding author email: dyy79@163.com \\ Tel:(+86)13909828288
}

Keywords: Resource-based city; Connotation; Definition; Development evaluation; Index system

\begin{abstract}
The definition of the connotation and extension of resource-based cities (regions) in China has encountered some problems, resulting in the emergence of different opinions that there are 80 to 426 resource-based cities in New China. This paper proposes that the connotation and extension of resource-based cities (regions) may have some adjustments in different time and space, but its essential content should be fixed, constant and universally applicable in the world; relative indicators should be employed as far as possible since the establishment of absolute indicators for the evaluation index system of transformation performance and development potential of resource-based regions often lacks comparability. In this paper, we have made great efforts in these aspects.
\end{abstract}

\section{Research status of connotation and extension of resource-based areas}

China's research on the connotation and extension of resource-based regions has encountered some problems, which leads to different statements about the number of resource-based cities in New China, for example, 80, more than 170, about 300, 426 and $262 .{ }^{1}$ In 2003, "118 resource-based cities" were officially authorized in China $^{2}$. Ten years later, in 2013, the number of authorized resource-based cities(regions) was expanded to 262, of which 128 were prefecture level cities (3.8 times that of 2003) and 62 county level cities (2.4 times that of 2003). ${ }^{3}$ In addition, it was authoritatively defined that "resource-based cities were cities that had risen or developed due to the exploitation of natural resources, and resource-based industries occupied a large share of industry." 4 This definition, on the one hand, did not indicate whether it was a local resource or not; Besides, the "large share" was too flexible and general to be held.

The authoritative definition in 2013 was that "Resource-based cities are the types that take the exploitation and processing of natural resources such as minerals and forests in this area as the leading industry." There were 3 specific indicators: mining function intensity, output scale coefficient and the degree of resource contribution. Cities that met one of the three indicators could be recognized as resource-based cities. What remains to be discussed in this definition and the three indicators are: First, leading industries usually refer to those industries or industrial sectors that are in the leading position of technology in the industrial system, and represent the direction or trend of industrial structure evolution. The resource-based industries of declining resource cities cannot play a role of "driving and promoting". Second, the points remain to be discussed in the indicators of the mining function intensity and the output scale coefficient are as described above.

In addition to the above two authoritative definitions, many others have also defined

\footnotetext{
1 Luhong Liu, Historical investigation and significance of the concept of resource-based city. Journal of Sichuan normal university (social science edition), September 2005

2 Research group of macroeconomic research institute, state planning commission. Macroeconomic research, no.11, 2002

3 Jianhui Yu, Jiaming li, Wenzhong Zhang. Identification and comprehensive classification of resource-based cities in China [J]. Acta Geographica Sinica, 2018, 73(4): 677-687

4 Research group of macroeconomic research institute, state planning commission. Macroeconomic research, no.11, 2002
} 
resource-based cities, such as Hu Kui, Zhang Shaojun... Zhou Liang (2017) proposed the definition of post resource-based cities, which is, the cities which have undergone a period of transformation, focused on the cultivation of new alternative industries and began to take shape instead of relying on resource consumption.

Resource-based Town (City), Mining Town (City), Company Town (City), etc. are used to describe resource-based cities in other countries, which mean resource-based, industry and mining industry, and energy resource. City and town represent the geographical scope ${ }^{5}$.

\section{Research status of development stage in resource-based areas}

Lucas first put forward the "four-stage development theory" of resource-based cities in 1971, including construction stage, development stage, transformation stage and maturation period, on the basis of which the "decline stage, closing stage" was added by Bradbury in 1979.

Han Fengqin et al. (2014) divided resource-based cities into initial resource-based cities, mature resource-based cities and exhausted resource-based cities, while Zhao Kangjie and Zhao Yujuan (2011) classified them into lightly dependent, moderately dependent and heavily dependent resource cities. Yu Jianhui, Li Jiaming (2018) pointed out the traditional classification method based on the division of dominant resource types and the division of urban development cycle.

\section{Research status of transformation performance and development potential in Resource-based Regions}

The evaluation index system in Annual performance assessment and evaluation methods for the transformation of resource-exhausted cities (trial) remains to be discussed in the following aspects: First, there is no GDP index. Second, there is no horizontal comparison index with the average level of the provinces and cities. Third, the index of "urban employment" should be changed to the urban registered unemployment rate, because the increase or decrease in employment sometimes cannot fully reflect the employment situation.

Niu Fei and Fu Yun (2007) analyzed the advantages and disadvantages of major evaluation methods for the transformation and development of resource-based cities, such as Delphi method, analytic hierarchy process, ecological footprint analysis approach, fuzzy comprehensive evaluation method, SVM method and entropy method. Ma Li et al. (2014) established an evaluation index system for the transformation of forestry resource-based cities from the four levels of economic system, social system, ecological system and resource system, including the target layer, system layer, element layer and index layer. Xu Jun (2011) constructed an evaluation index system for industrial transformation of resource-based cities from seven aspects: industrial growth potential, correlation, economic benefits, and comparative advantages, industrial scientific and technological progress, industrial human resource quality, and social benefits.

\section{The author's definition of the connotation and extension of resource-based regions}

\subsection{Connotation}

As a scientific concept, the connotation and extension of resource-based regions essential content should be fixed, constant and universally applicable. Therefore, our research group defines the connotation of resource-based regions as follows: Resource-based regions refer to the regions where the mining and processing of local mineral resources or forest resources is the leading or pillar industries. It contains the following four levels of meanings: First, resources include mineral resources and forest resources; second, the mining and processing of local resources; third, the mining and processing industries should be leading industries or pillar industries; fourth, regions formed by certain population, land and economic activities.

\footnotetext{
5 Luhong Liu, Historical investigation and significance of the concept of resource-based city. Journal of Sichuan normal university (social science edition), September 2005
} 


\subsection{Extension}

The extension of resource-based regions is defined as follows from the perspective of population and land scale: industrial and mining areas, towns, county-level cities, and prefecture-level cities. Our research group defines the extension of resource-based regions as follows from the perspective of life cycle: pre-resource-based regions, growing resource-based regions, mature resource-based regions, exhausted resource-based regions, post-resource-based regions, as shown in Figure 1.

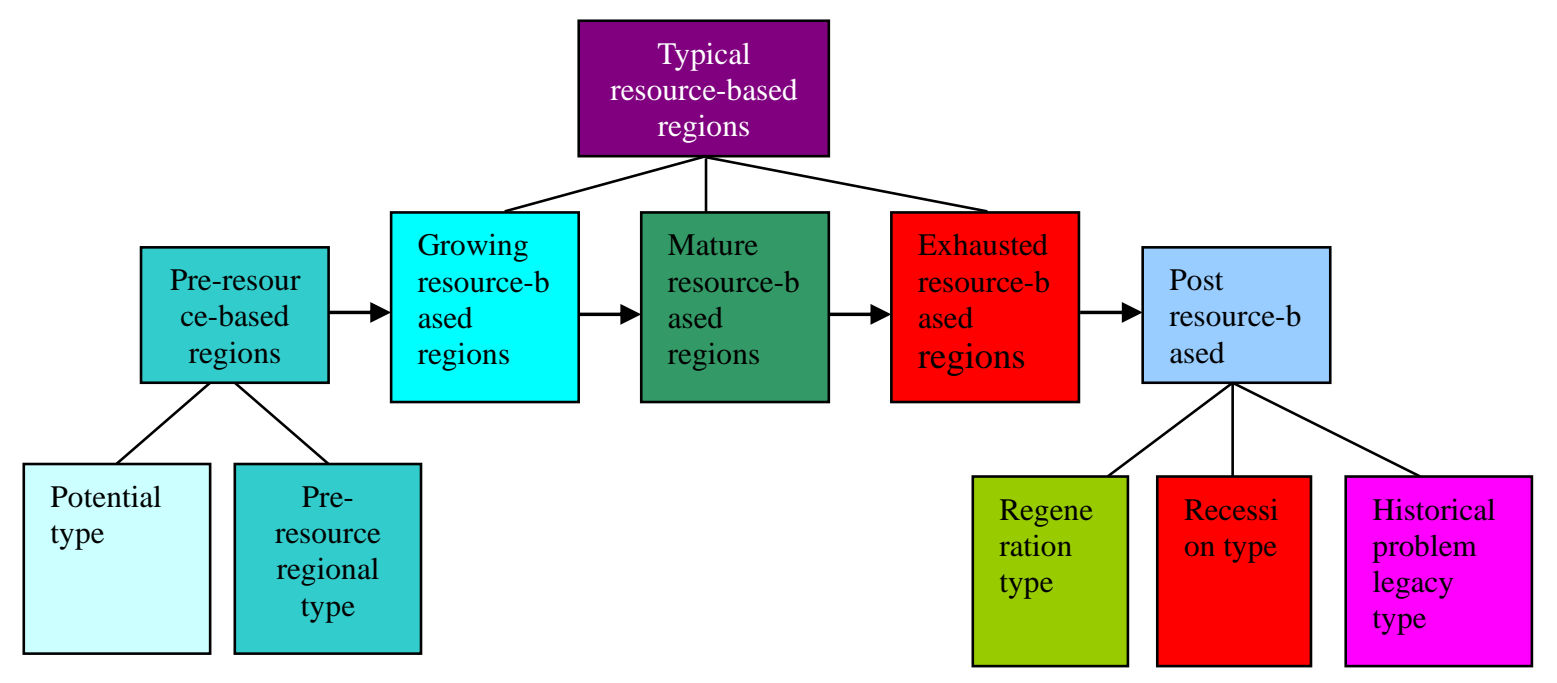

Fig 1. definition of Resource-based Region Extension from the perspective of life cycle

As shown in Figure 1, pre-resource-based regions refer to regions where the mineral or forest resources have exploitable reserves but have not been mined or have been mined and processed, but the resource industries have not become the dominant or pillar industries, including potential resource-based regions and quasi-resource-based regions.

Post-resource-based regions are regions that after experiencing the development stage of the typical resource-based regions, although the mining and processing of mineral resources or forest resources are still or will not be carried out in this region, the resource industry is no longer the leading industry or pillar industry. Among them, the regeneration type means that new alternative industries become the leading or pillar industries in the regions instead of the resource-based industries, and the transformation has been successful.

\subsection{The author's construction of the evaluation index system for the transformation performance and development potential of resource-based regions}

Principles for selecting indicators: First, Comparability. Considering that the scale of 262 resource-based regions in China has considerably different conditions. Based on the above difference, it is inappropriate to compare absolute indexes when we make comparisons of their development potential. Thus, relative indexes are adopted as far as possible. Second, Particularity. The selection of indicators should be as consistent as possible with ordinary areas. There are five first-level indicators in the evaluation index system designed by the research group, among which "resource development" reflects the characteristics of resource-based regions. There are 26 secondary indicators, six of which reflect the characteristics of resource-based regions. If the indicators that reflect the characteristics of resource-based areas are discarded, then the development potential can be compared with that of ordinary areas. If a region or a type of region or a national resource-based region is compared with itself at a certain point in the past, it can be concluded whether it has development potential and its size. Third, Accessibility. In addition to six indicators reflecting the characteristics of resource-based areas, other indicators can be found in the statistical yearbook, as shown in table 1. 
Table 1 development potential evaluation index system of resource-based regions

\begin{tabular}{|c|c|c|c|c|c|c|c|c|}
\hline \multicolumn{2}{|c|}{ Level indicator } & \multicolumn{3}{|c|}{ Secondary indicator } & \multicolumn{3}{|c|}{ evaluation criteria } & \multirow{3}{*}{ score } \\
\hline name & weight & $\begin{array}{c}\text { Seral } \\
\text { number }\end{array}$ & name & weight & Level 1 & Level 2 & Level 3 & \\
\hline $\begin{array}{c}\text { Resource } \\
\text { development }\end{array}$ & 0.2 & 1 & $\begin{array}{l}\text { Development stage (based } \\
\text { on the type identified by the } \\
\text { state in 2013) }\end{array}$ & & recession & $\begin{array}{l}\text { Growth } \\
\text { mature }\end{array}$ & regeneration & \\
\hline \multirow{7}{*}{$\begin{array}{c}\text { Economic } \\
\text { development }\end{array}$} & \multirow{7}{*}{0.3} & 2 & Per capita GDP (yuan) & 0.2 & Lower than & Equal to & Higher than & \\
\hline & & 3 & $\begin{array}{l}\text { The proportion of the total } \\
\text { output value of the leading } \\
\text { resource mining (logging) } \\
\text { industry in the total } \\
\text { industrial output value }(\%)\end{array}$ & 0.2 & Higher than & Equal to & Lower than & \\
\hline & & 4 & $\begin{array}{l}\text { The proportion of the total } \\
\text { output value }(\%)\end{array}$ & 0.2 & Lower than & Equal to & Higher than & \\
\hline & & 5 & $\begin{array}{l}\text { Total fixed asset investment } \\
\text { per capita(yuan) }\end{array}$ & 0.1 & Lower than & Equal to & Higher than & \\
\hline & & 6 & $\begin{array}{l}\text { The per capita budget } \\
\text { revenue of the public } \\
\text { finance(yuan) }\end{array}$ & 0.1 & Lower than & Equal to & Higher than & \\
\hline & & 7 & $\begin{array}{l}\text { The proportion of } \mathrm{R} \& \mathrm{D} \\
\text { investment in } \mathrm{GDP}(\%)\end{array}$ & 0.1 & Lower than & Equal to & Higher than & \\
\hline & & 8 & $\begin{array}{c}\text { Energy consumption per } \\
\text { unit of GDP }\end{array}$ & 0.1 & Higher than & Equal to & Lower than & \\
\hline \multirow{8}{*}{$\begin{array}{c}\text { People's } \\
\text { livelihood } \\
\text { improvement }\end{array}$} & \multirow{8}{*}{0.2} & 9 & $\begin{array}{l}\text { The average salary of on- } \\
\text { the-job workers(yuan) }\end{array}$ & 0.2 & Lower than & Equal to & Higher than & \\
\hline & & 10 & $\begin{array}{l}\text { The per capita disposable } \\
\text { income of permanent } \\
\text { urban residents(yuan) }\end{array}$ & 0.1 & Lower than & Equal to & Higher than & \\
\hline & & 11 & $\begin{array}{l}\text { The per capita disposable } \\
\text { income of permanent rural } \\
\text { residents(yuan) }\end{array}$ & 0.1 & Lower than & Equal to & Higher than & \\
\hline & & 12 & $\begin{array}{l}\text { The registered urban } \\
\text { unemployment rate }(\%)\end{array}$ & 0.2 & Higher than & Equal to & Lower than & \\
\hline & & 13 & $\begin{array}{l}\text { The consumption level of } \\
\text { all residents(yuan/person) }\end{array}$ & 0.1 & Lower than & Equal to & Higher than & \\
\hline & & 14 & $\begin{array}{c}\text { Saving deposit } \\
\text { balance(yuan/person) }\end{array}$ & 0.1 & Lower than & Equal to & Higher than & \\
\hline & & 15 & $\begin{array}{l}\text { The average residential } \\
\text { floor area (square meters) }\end{array}$ & 0.1 & Lower than & Equal to & Higher than & \\
\hline & & 16 & $\begin{array}{l}\text { The completion rate of } \\
\text { Shantytown reconstruction } \\
\text { task } \quad(\%)\end{array}$ & 0.1 & Lower than & Equal to & Higher than & \\
\hline \multirow{5}{*}{$\begin{array}{l}\text { Environmental } \\
\text { remediation }\end{array}$} & \multirow{5}{*}{0.2} & 17 & $\begin{array}{l}\text { General industrial solid } \\
\text { waste production(tons) }\end{array}$ & 0.2 & Higher than & Equal to & Lower than & \\
\hline & & 18 & $\begin{array}{c}\text { The comprehensive } \\
\text { utilization rate of industrial } \\
\text { solid waste }(\%)\end{array}$ & 0.2 & Lower than & Equal to & Higher than & \\
\hline & & 19 & $\begin{array}{l}\text { The recovery and treatment } \\
\text { rate of geological } \\
\text { environment in mines left } \\
\text { over from history }(\%)\end{array}$ & 0.2 & Lower than & Equal to & Higher than & \\
\hline & & 20 & $\begin{array}{c}\text { The reclamation rate of } \\
\text { damaged land left over from } \\
\text { history }(\%)\end{array}$ & 0.2 & Lower than & Equal to & Higher than & \\
\hline & & 21 & $\begin{array}{c}\text { Land reclamation rate of } \\
\text { historical goaf }(\%)\end{array}$ & 0.2 & Lower than & Equal to & Higher than & \\
\hline \multirow{4}{*}{ infrastructure } & \multirow{4}{*}{0.1} & 22 & $\begin{array}{l}\text { Per capita land area (square } \\
\text { kilometers) }\end{array}$ & 0.2 & Lower than & Equal to & Higher than & \\
\hline & & 23 & $\begin{array}{c}\text { Highway mileage per } \\
\text { capita(kilometers) }\end{array}$ & 0.2 & Lower than & Equal to & Higher than & \\
\hline & & 24 & $\begin{array}{l}\text { per capita beds in health } \\
\text { institutions (number) }\end{array}$ & 0.2 & Lower than & Equal to & Higher than & \\
\hline & & 25 & $\begin{array}{l}\text { the proportion of technical } \\
\text { personnel in employees }(\%)\end{array}$ & 0.2 & Lower than & Equal to & Higher than & \\
\hline
\end{tabular}




\begin{tabular}{|l|l|c|c|c|c|}
\hline 26 & $\begin{array}{c}\text { The number of students } \\
\text { above technical secondary } \\
\text { school(ten thousand people) }\end{array}$ & 0.2 & Lower than & Equal to & Higher than \\
\hline score & & & \\
\hline
\end{tabular}

Note: "lower than, equal to, higher than" in the evaluation criteria refers to the comparison with the average level of the local provinces and cities.

Relying on the index system, we can better understand the exploitation potential of different types of resources, the development potential of regions with different types of resourcesas well asnational resource-based regions, and provide decision-making basis for the overall framework and implementation path of the transformation and development of resource-based regions in the new era.

\section{Reference}

[1] Li Haiming, Research on the Sustainable Development of Resource-based Cities in Liaoning Province, Liaoning People's Publishing House, 2012.

[2] Gao Jian, Wu Xiaoxia, Research on the Supporting Policies for the Breakthrough Development of the transformation of Shanxi's Resource-based Economy, Economic Issues, Issue 9, 2018.

[3] Yu Jianhui, Li Jiaming, Zhang Wenzhong, Identification and Comprehensive Classification of Resource-based Cities in China[J], Acta Geographica Sinica, 2018, 73(4): 677-687.

[4] Wang Qiaoli, Han Lihong, Research on Industrial Transformation Efficiency of Resource-based Cities Based on DEA Model: A Case Study of Prefectural Resource-based Cities in the Three Provinces of Northeast China, Resources \& Industries, Volume 19, Issue 1, February 2017. 